\title{
Sustainable Tourism or Selling Places: Effects of the UNESCO World Heritage Site Nomination in Valparaíso and Hoi A
}

\author{
Matías Muñoz Hernández
}

\begin{abstract}
The strategy of promoting culture through city image is strongly related to UNESCO strategy to develop particular cities through their World Heritage Program. This research focuses on heritage infrastructure and the entanglement with cultural investment, which are based in specific buildings commonly constituted as highly cultural valuable assets. This research takes two independent case studies to compare the demographic, economic and social effects on Valparaíso, Chile and Hoy An, Vietnam after their nomination as a World Heritage Site. The results on both cities are contrasted analysing the slots distribution of the heritage sites and their activity before and after the nomination. The findings of this study show that the nomination's positive effects on tourism depend on the empowerment of the local government to manage the heritage site; additionally, it is restricted to the political context of each country. Therefore, the nomination by UNESCO does not guarantee a positive contribution in terms of city branding. On the contrary, an inefficient administration of the heritage site can originate an overexploitation of the site and a redistribution of the demographic characteristics. In the end, the nomination for World Heritage Site not only represents touristic benefits for the city but al so holds complex responsibilities on the strategy to sell the city/town brand. It appears that recognizing the global plan of the UNESCO World Heritage Site in a national and local sphere context is the most effective way to transmit an authentic experience for the tourists, ensure the sustainability of the cultural investment and respect the interests of the local community.
\end{abstract}

\section{Keywords:}

World Heritage Site, city branding, UNESCO, sustainable tourism.

\section{Introduction}

This research explores the connection between selling culture and selling places, in particular where the connection between them both is sustainable tourism. In this context, economic growth, together with equal benefits for local people are the main concerns of debate ${ }^{1}$. As James ${ }^{2}$ states: 'sustainable tourism is thus a comprehensive concept of balancing economic needs and desires with equity, awareness, and integrity regarding human concerns’.

Among the relevant aspects of selling cities is the instrumentality of local authenticity in regards to educational and artistic activities which engage visitors with the local way of life $\mathrm{e}^{3}$. The instrumentality of tourism towards economic and environmental improvements followed North America law, where 250 convention and cultural centres were created between 1976 and 1986. Within that specific period, tourism and gentrification were the variables through which decayed cities were reactivated ${ }^{4}$. However, cultural investment faces two major issues: efficiency in resource allocation, and equality of access to all main resources ${ }^{5}$. Hence, a successful investment in cultural tourism reinforces the development of the site as well as the attachment to local identity. As Griffiths ${ }^{6}$ highlights, part of the strategies that consider culture a subject for urban regeneration depend upon the cultural policy of the city, the advantages of local authorities' structures, and the funding sources from both governmental and international entities.

\footnotetext{
'Gareth Shaw and Allan Williams. Critical Issues in Tourism: A Geographical Perspective. (Oxford: Blackwell Publishing, 2002)

${ }^{2}$ Ursula James. "Real Culture Preservation. Authenticity, and Change in Hoi An's Heritage Tourism Industry" Independent Study Project (ISP) Collection. 873,2010

${ }^{3}$ Harry Coccossis. "Sustainable Development and Tourism: Opportunities and Threats to Cultural Heritage from Tourism." in Cultural Tourism and Sustainable Local Development, ed. Luigi Fusco Girard and Peter Nijkamp, (Surrey: Ashgate Publishing Limited, 2009), 47-56.

${ }^{4}$ Gareth Shaw and Allan Williams. Critical Issues in Tourism: A Geographical Perspective. (Oxford: Blackwell Publishing, 2002)

${ }^{5}$ Christian Ost. "Cultural Heritage, Local Resources and Sustainable Tourism: Towards an Operational Framework for Policy and Planning." in Cultural Tourism and Sustainable Local Development, ed. Luigi Fusco Girard and Peter Nijkamp, (Surrey: Ashgate Publishing Limited, 2009), 75-80.

${ }^{6}$ Ron Griffiths. "Cultural Strategies and new modes of urban intervention.” Cities 12, no. 4 (1995): 253-265.
} 
This research focuses on heritage infrastructure and its entanglement with cultural investment, both of which in turn are based around specific buildings commonly constituted as assets with high cultural value. Within this context, historical places are one of the instruments used to sell culture and attract individuals within the cultural tourism context. For this particular study, the promotion strategy uses cultural heritage as a tool to sell the city/town. Heritage, in this sense, represents all the intrinsic art manifested in a specific place ${ }^{7}$.

This investigation considers two practical examples. Both case studies are from urban areas in developing countries whose image and infrastructure are their main attractions and are used in promoting branding of the city/town to tourists. Hội An is an ancient town described as a museum itself ${ }^{8}$, while Valparaíso holds cultural and architectural value in its historic port and the surrounding constructions and buildings of its hills. Moreover, they are both part of the World Heritage List (WHL); such an international recognition from UNESCO would guarantee international investment in infrastructure, and consequently generate more tourism. In this context, UNESCO's global strategy since $1994^{9}$ has been to invest in the preservation and diversity of World Heritage.

\section{ValparaÍso}

The city of Valparaíso was added to the WHL in $2003^{10}$. The heritage area is the old town of Valparaíso, an example of the late $19^{\text {th }}$ century architecture. The protected area is $0.9 \%$ of the urban area and is comprised of three neighbourhoods: Puerto Financiero, Cerro Concepción and Cerro Alegre, which together are constituted as a natural amphitheatre and urban ensemble ${ }^{11}$. The municipality of Valparaíso runs the administration of the heritage sites; however, national law does not recognise municipalities as relevant policy-making institutions, but administrative institutions that apply central decisions ${ }^{12}$. Thus, the local community is removed from the priorities of the city's urban strategies. On the other hand - considering the wider political context of Chile - public institutions are a weak point and private stakeholders hold more influence in preserving the heritage site and the guidelines for their care. Real estate companies have started to refurbish old buildings, having taken on most of the improvement work ${ }^{13}$.

Private initiatives try to mitigate the lack of support whilst simultaneously encouraging the public sector to take part in the responsibility of the heritage site. This is the case of RPUDV (Recovery Program and Urban Development Valparaíso) that

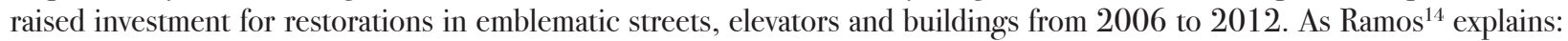
'25 million USD was awarded by the Inter-American Development Bank (IDB), and 48 million USD by the Chilean state'. He defined five integrated heritage spaces (hills Alegre, Concepción, Toro, Santo Domingo and Cordillera) to run 94 initiatives within six years.

The nomination to WHL and the development of tourism generated modifications in the main economic activities of the city: such as- changing the use of Baron Quay, initially designated for port activities but then modified to develop a shopping mall ${ }^{15}$. This action was achieved due to private sector influence on the city's urban planning through public tenders despite a lack of integral urban policy development by government entities to integrate heritage, social cohesion and economic activity ${ }^{16}$. Even

\footnotetext{
${ }^{7}$ Andy Pratt. "The relationship between the City, Cultural Tourism and the Cultural Industries." Cultural Tourism. (Jan 2002): 33-45.

${ }^{8}$ UNESCO. IMPACT: The effects of Tourism on Culture and the Environment in Asia and the Pacific: Cultural Tourism and Heritage Management. (UNESCO: Bangkok, 2008).

9 “Global Strategy." UNESCO, accessed April 12, 2017, http://whc.unesco.org/en/globalstrategy/.

${ }^{10}$ UNESCO. "Historic Quarter of the Seaport City of Valparaíso." WHC nomination documentation, July 5, 2003, http://whc.unesco.org/uploads/ nominations/959rev.pdf.

${ }^{11}$ Rodrigo Hidalgo, Axel Borsdorf and Gabriel San Martín. "Socio-spatial change in the world heritage site Valparaíso." Journal of the Geographical Society of Berlin 144 no.3 (2013): 228-240.

${ }^{12}$ Egon Montecinos. "Los actuales desafios regionales en Chile: ¿Nueva Regionalización o más Descentralización? XI Asamblea de las municipalidades” XI Congreso Nacional de Municipalidades, _January 8,9,10,2013, http://munitel.cl/eventos/seminarios/html/documentos/2013/XI_ASAMBLEA_ DE_MUNICIPALIDADES/CONGRESO/PPT10.pdf.

${ }^{13}$ Rodrigo Hidalgo, Axel Borsdorf and Gabriel San Martín. "Socio-spatial change in the world heritage site Valparaíso.” Journal of the Geographical Society of Berlin 144 no.3 (2013): 228-240.

${ }^{14}$ Natalia Ramos. "Report reveals that only 50\% was completed in Valparaíso patrimonial work.” La Bicicleta Verde, June 30, 2013 , https://labicicletaverde. com/report-reveals-that-50was-completed-in-valparaiso-patrimonial-works/

15 “Así será el Nuevo Mall Barón en Valparaíso”, El Martutino, accessed April- 30, 2017, http://www.elmartutino.cl/noticia/sociedad/fotos-asi-serael-nuevo-mall-baron-en-valparaiso

${ }^{16}$ Margarita Morales. Cultural Heritage and Urban Regeneration: The conflict-between Identity and Development Strategies in the city of Valparaiso (UCL: Bartlett school of graduate studies University College London, 2013).
} 
though the number of cultural plots has increased from 1 to 7 between 2003 and 2011, the number of commercial plots has risen from 16 to 76 ; reflecting the consequences of the exposure of the heritage site to tourism ${ }^{17}$.

The designation of heritage brought new issues; especially as regards the socio-spatial problems of the city. During 2003 to 2011, 6,926 new commercial licenses were granted, and the residential area of the heritage site diminished 40\% (Figure 1 and Figure 2). Furthermore, Valparaíso ranks highly as the region with most creative companies in the country - 1,273 creative firms ${ }^{18}$ - mainly an effect of the re-generation that the city is experiencing.

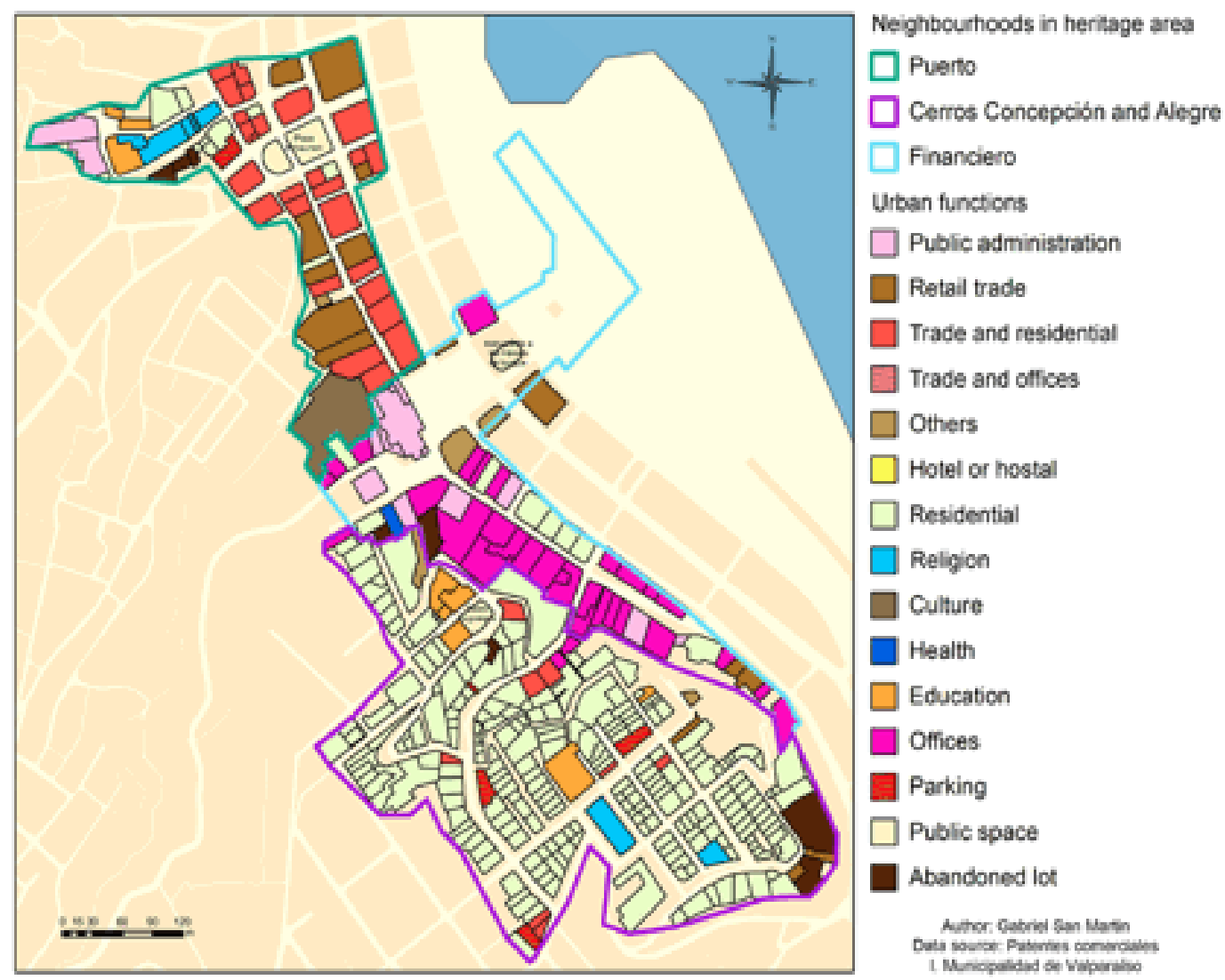

Fig. 1. Slots distribution on the heritage site of Valparaíso in 2003.

Source: Rodrigo Hidalgo, Axel Borsdorf and Gabriel San Martín. "Socio-spatial change in the world heritage site Valparaíso." Journal of the Geographical Society of Berlin 144 no.3 (2013): 228-240.

\footnotetext{
${ }^{17}$ Rodrigo Hidalgo, Axel Borsdorf and Gabriel San Martín. “Socio-spatial change in the world heritage site Valparaíso." Journal of the Geographical Society of Berlin 144 no.3 (2013): 228-240.

${ }^{18}$ INE, Estadísticas Culturales: Informe Anual 2015. (Santiago: A Impresores S.A, 2016).
} 


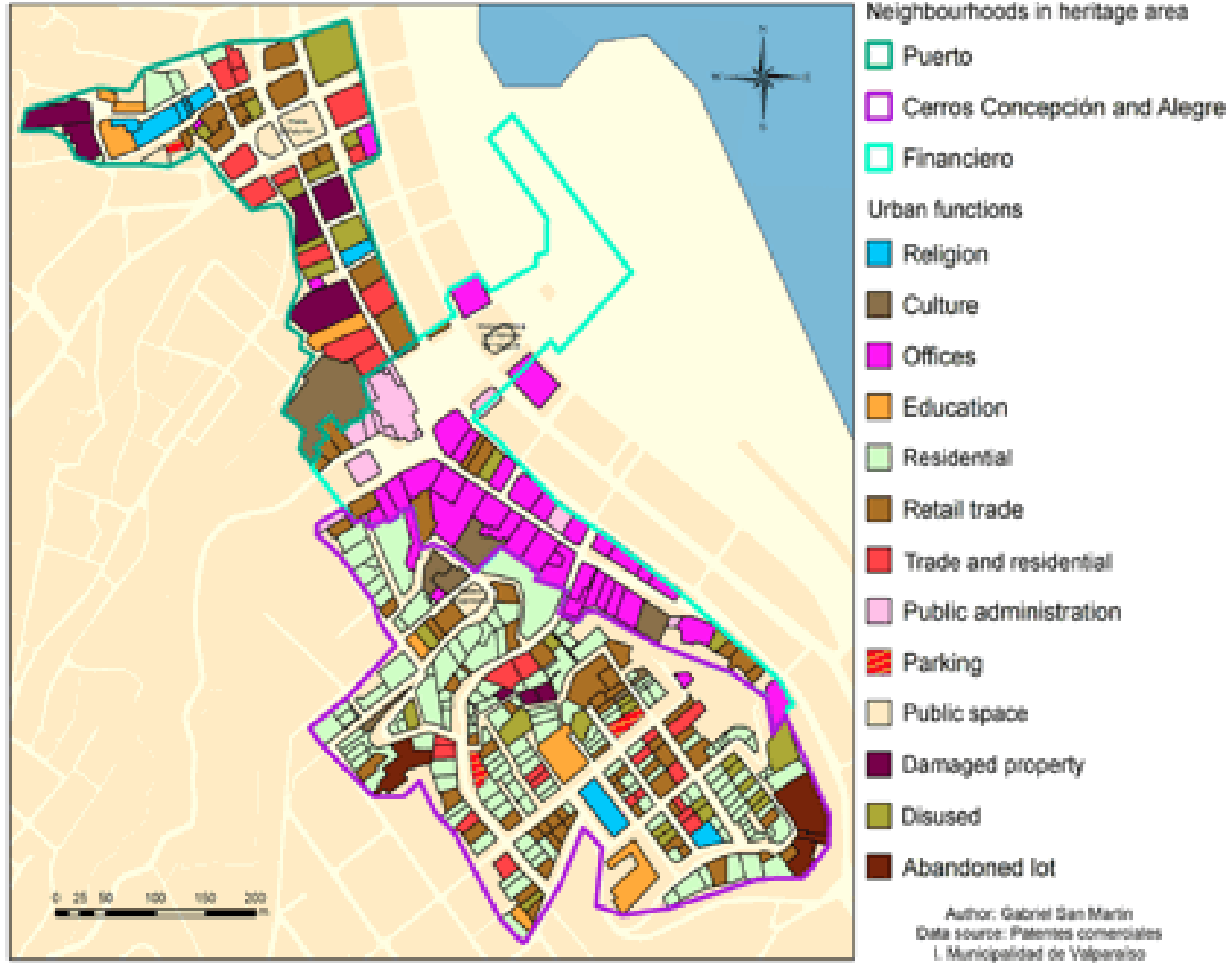

Fig. 2. Slots distribution on the heritage site of Valparaíso in 2011.

Source: Rodrigo Hidalgo, Axel Borsdorf and Gabriel San Martín. "Socio-spatial change in the world heritage site Valparaíso." Journal of the Geographical Society of Berlin 144 no.3 (2013): 228-240.

For Valparaíso, the promotion of the city started from the UNESCO nomination based on a heritage perspective, considering the infrastructure of the buildings of certain hills. But afterwards, arts and creative industries have complemented the image of Valparaíso through the implementation of annual festival ${ }^{19}{ }^{20}$ and the creation of a significant cultural centre ${ }^{21}$ in 2012.

Consequently, art has contributed to urban regeneration, in the sense that the process of selling the city to tourists is being implemented via a strategy in which artistic industries helps to promote the city by organizing festivals and creating an art zone in the city centre ${ }^{22}$. However, the redistribution of residents implies that a significant amount of local people have had to move out of the area, and as new young professionals migrated to the city consequently raising real estate value, the overall makeup of the area has been marked by an increasing number of business licenses granted in the heritage site.

To sum up, the nomination created a reduction of living spaces, and consequently deteriorated the socio-economic situation of the local community that stayed agglomerated in those areas specified as within the heritage site.

\section{HộI AN}

This ancient site is a rural touristic attraction. Hội An is a small town which attributes its cultural value to the multinational architectonical influences upon its infrastructure. During the $16^{\text {th }}$ and $17^{\text {th }}$ centuries, the town was occupied variously by

\footnotetext{
19 "Festival de las Artes 2017" Festival de las Artes, accessed March 15, 2017. http:/ / festivaldelasartes.cultura.gob.cl/.

20 "Festival Mil Tambores", Mil Tambores, accessed March 15, 2017.http://www.miltambores.cl/.

21 "Parque Cultural Valparaíso” Parque Cultural Valparaíso, accessed February-22, 2017. http://parquecultural.cl/.

${ }^{22}$ Ron Griffiths. "Cultural Strategies and new modes of urban intervention.” -Cities 12, no. 4 (1995): 253-265.
} 
Chinese, Japanese, Dutch, Spanish and French communities, the town's constitution being that of an international trading port $^{23}$.

The initiative of promoting the area through culture started in 1985 when Hội An became a national heritage site. Vietnam historically opened its doors to tourism in 1988, along with the creation of the Vietnamese National Administration of Tourism (VNAT) in order to manage it ${ }^{24}$. Subsequently, after its nomination as a world heritage site in December 199925, (UNESCO, 1999), international resources and support from UNESCO have been integrated into the local area. In terms of visitors, the number of tourists increased from 3,400 in 1991 to 188,315 in $1999^{26}$. This explosion of tourists is a consequence of a national strategic plan to invest in the Vietnamese cultural brand with the promotion of heritage sites such as Phong Nha-Kẻ Bàng national park, Mỹ Sơn sanctuary, Hué Monuments and Hạ Long Bay ${ }^{27}$.

The preservation area of Hội An is divided into two zones; the first, the ancient town, which has buildings divided into four subcategories - I to IV and a Special Category consisting of the most critically important historical buildings, 79 out of a total 1,254 buildings $^{28}$. The second 'buffer' zone is mainly constituted of surrounding areas of the architectonical heritage site (Figure 3).

Table 1. Contribution for private owned ancient houses in Hội $\mathrm{An}^{29}$.

\begin{tabular}{|c|c|c|c|c|}
\hline & \multicolumn{2}{|c|}{ Located on main roads } & \multicolumn{2}{c|}{ Located in small lanes or Alleys } \\
\hline Category & $\begin{array}{c}\text { Government } \\
\text { support(\%) }\end{array}$ & $\begin{array}{c}\text { Owner } \\
\text { contribution } \\
(\%)\end{array}$ & $\begin{array}{c}\text { Government } \\
\text { support (\%) }\end{array}$ & $\begin{array}{c}\text { Owner } \\
\text { contribution } \\
(\%)\end{array}$ \\
\hline Special & 60 & 40 & 75 & 25 \\
\hline $\begin{array}{c}\text { Categories 1 } \\
\& 2\end{array}$ & 45 & 55 & 65 & 35 \\
\hline $\begin{array}{c}\text { Categories 3 } \\
\& 4\end{array}$ & 40 & 60 & 60 & 40 \\
\hline
\end{tabular}

Source: UNESCO. IMPACT: The effects of Tourism on Culture and the Environment in Asia and the Pacific: Cultural Tourism and Heritage Management (Bangkok: UNESCO, 2008).

\footnotetext{
${ }^{23}$ Tuyet Nhung. "Hoi An Old Town - an ancient Beauty of Vietnam" Vietnam-Beauty.com, August 7, 2008, http://www.vietnam-beauty.com/topdestinations/destination-in-the-central-region/12-destination-in-the-middle/43-hoi-an-old-town-an-ancient-beauty-of-vietnam.html

${ }^{24}$ Tomke Lask and Stefan Herold. “An Observation Station for Culture and Tourism in Vietnam: A Forum for World Heritage and Public Participation.” in The Politics of World Heritage, ed. David Harrison and Michael Hitchcock, Bristol: Channel View Publication, 2005. 119-131.

${ }^{25}$ UNESCO. "Hoi An Ancient Town." WHC nomination documentation, December 4, 1999, http://whc.unesco.org/uploads/nominations/948.pdf ${ }^{26}$ UNESCO. Culture Heritage Management and Tourism: Models for Co-operation among Stakeholders. A case study on Hoi An Vietnam (Bhaktapur: UNESCO, 2000).

${ }^{27}$ UNESCO. IMPACT: The effects of Tourism on Culture and the Environment-in Asia and the Pacific: Cultural Tourism and Heritage Management (Bangkok: UNESCO,2008).

${ }^{28}$ UNESCO. IMPACT: The effects of Tourism on Culture and the Environment-in Asia and the Pacific: Cultural Tourism and Heritage Management (Bangkok: UNESCO, 2008).

${ }^{29}$ UNESCO. IMPACT: The effects of Tourism on Culture and the Environment-in Asia and the Pacific: Cultural Tourism and Heritage Management (Bangkok: UNESCO, 2008)
} 


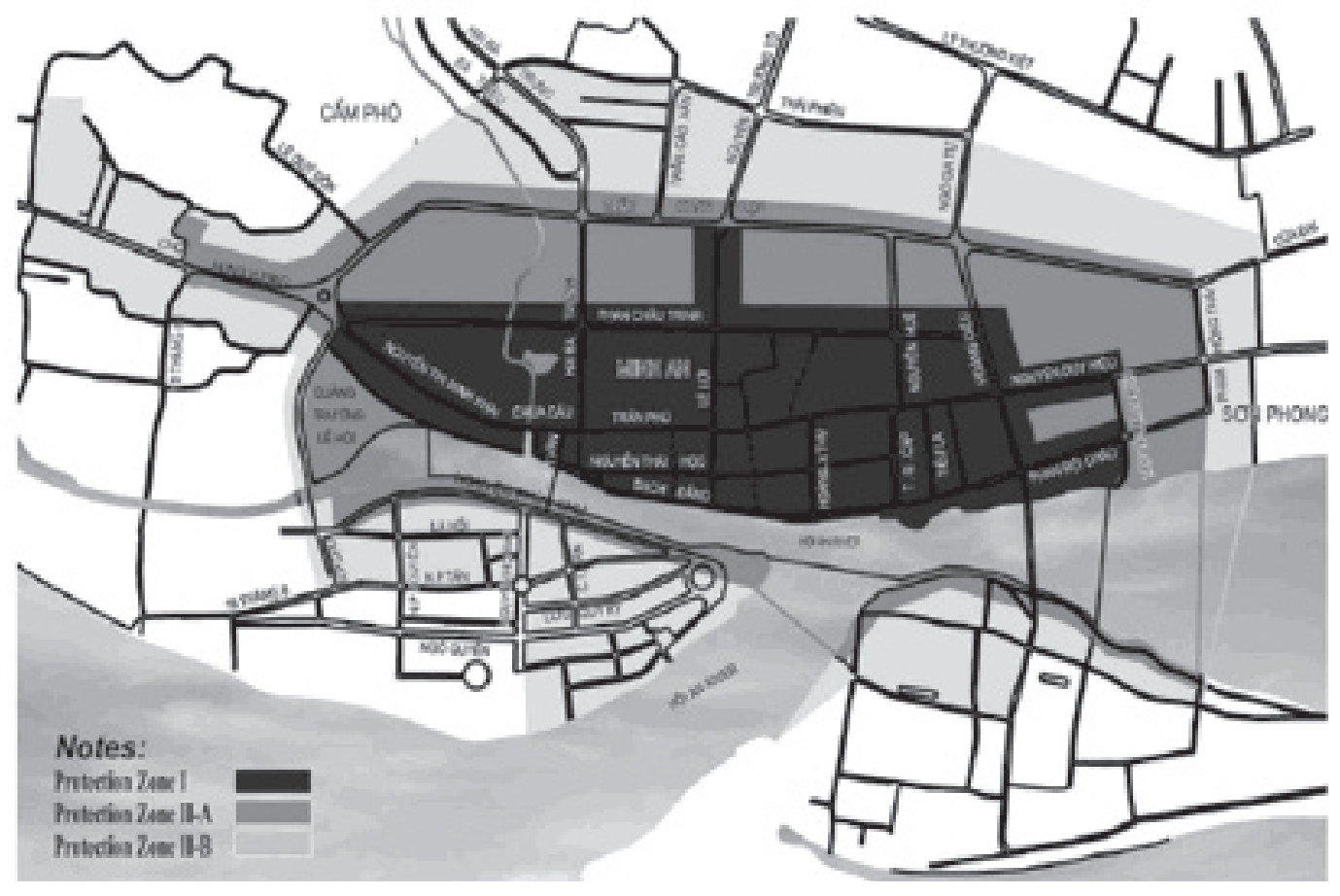

Fig. 3. Zone distribution on the heritage site of Hội An.

Source: UNESCO. IMPACT: The effects of Tourism on Culture and the Environment in Asia and the Pacific: Cultural Tourism and Heritage Management (Bangkok: UNESCO, 2008).

For Hội An, the strategy of preservation was first designed by the Cultural Heritage Law of the Vietnam Government, and the Hội An People’s Committee Statute of Managing, Preserving and Utilising the Hội An Ancient Town who nominated the ancient town for the World Heritage List of UNESCO. Nowadays, the local city government is the main authority in charge of the conservation project. The cultural investment started with government-owned heritage buildings of which $45.5 \%$ of its funds come from the municipal government, $49.5 \%$ comes from national and provincial governments and $5 \%$ from international donors. Additionally, privately owned buildings are also eligible to seek for support, but the percentage of public resources depends on the location of the building and the category into which the building falls. The infrastructure investment is represented in Table 1. The cultural investment of Hội An noticeably lacks support for houses that do not have a high heritage value yet are still in the town. Therefore, less privileged residents receive a smaller contribution ${ }^{30}$, inequality in this way becoming an important consideration as regards problems relating to this situation.

Despite these contributions, investment in cultural infrastructure remains incomplete without the intervention of smaller art projects contributing to heritage and identity on a scale where principal guidelines do not and cannot reach ${ }^{31}$. One example is Réhahn, a French photographer that opened a free art gallery museum based on the Vietnamese culture in Hội An ${ }^{32}$. Such an external contribution helps in promoting the town regardless of international or government guidelines.

Growth in tourism has caused negative externalities, such as pollution, associated with the traffic increase in public spaces, loss of wetlands surrounding the town and the consequences of greater strain on insufficient wastewater treatment facilities in the area $^{33}$. In this regard, local authorities are the only ones concerned with protecting the old traditions of the town, rather than focusing on economic goals. This policy comes into conflict with the macro guidelines of the 'Global Strategy' developed by

\footnotetext{
${ }^{30}$ André Alexander, Maurice Leonhardt and Huong Nguyen. Hoi An, Vietnam Mission Report (Bangkok: ACHR Asian Heritage Project, 2011).

${ }^{31}$ Graeme Evans. "Measure for Measure: Evaluating the Evidence of Culture's Contribution to Regeneration.” Urban Studies 42, no.5 (2005): $959-983$.

${ }^{32}$ Nguyen Dong. "French Photographer opens art gallery museum to preserve Vietnam's ethnic culture” Tuoi Tre News, January 23, 2017,http:// tuoitrenews.vn/lifestyle/39304/french-photographer-opens-art--gallery-museum-to-preserve-vietnams-ethnic-culture.

33 Julia Babcock. "Vietnam's Hoi An and The Resilience of Culture" Ecotrust, February 19, 2013, https://ecotrust.org/hoi-an-vietnam-and-theresilience-of-culture/
} 
UNESCO which focuses more heavily on tourism.

Another critical effect of selling cities is that the core activities of such places can change: for Hội An, the contribution of the agricultural and fish trades was relevant before the tourism boom after achieving heritage status. After Vietnam's opening to tourism, it expanded significantly to the main economic contributor of the city, contributing $68 \%$ of its GDP. The effect on residents was a marked increase in their economic capacity, consequently raising income per capita from US $\$ 417$ in 2000 to US $\$ 1,558$ in $2013^{34}$.

On the other hand, most tourists visit Hội An to experience the 'authenticity'of this unique town's varied history. Nevertheless, using preservation as a commodity has its drawbacks, especially for those residents who want a share in progress in a protected town where electronic shops and motorised vehicles are banned ${ }^{35}$. Consequently, preserving Hội An’s pre-19 ${ }^{\text {th }}$ century features requires a trade-off between being a great tourist attraction whilst also providing a proportionally great quality of life and development of local residents.

\section{Critical Analysis}

In the context of branding strategies for selling cities, three relevant stakeholders interact and struggle among the terms of their own interests. Firstly, the authorities both national and international represented by the local government and UNESCO whose authority provides the mandate of preservation. Secondly, the local residents of the city or town in which tourist policies and strategies impact directly their quality and way of life. Finally, tourists, whose demands and expectations have the power to alter the plans of authorities based on their demand for an authenticity of their cultural experiences in the city or town. These three roles interact in the two major problems of selling cities: sustained economic growth derived from investment in cultural infrastructure, and equity in the benefits this brings for local people.

Among the biggest concerns that cultural investment from the UNESCO WHL project brings is its potential for imposing a global strategy that does not take in consideration the negative social, environmental and economic externalities in the local sphere. Their top-down policies make it difficult for the local authorities to intervene, and moreover often transgress the interests of local people and national authorities ${ }^{36}$. Despite this, the competitive advantage compared to other touristic attractions that such usage of UNESCO brand for placing branding brings is often stronger than the negative externalities of tourism, in the sense that countries expect to capitalize the UNESCO brand in their touristic campaigns ${ }^{37}$.

Even though the first step to nominate a city or town for the WHL starts at local government level, the situation of national urban policy is complicated as far as global connections and international institutions have also taken policy guidelines ${ }^{38}$. However, the effectiveness of the implementation of urban policy still relies on national and local organizations.

Tourism based on cultural investment leads not only to the development of facilities and infrastructure for local people, but foreign exchange earnings, wider employment, and increased government revenues ${ }^{39}$. Yet it is argued that public revenue should not be taken into account, since the heritage site is not a commercialised good, and this perspective can entail conflicts of interests in terms of future development of the heritage site, and all too easily disrespects the wishes and willingness of the community to manage the investment of their own heritage. Harrison ${ }^{40}$ illustrates the conflict of interests of cultural investment: 'We - and the term is used advisedly - "perform" heritage for the benefit of people who are not "us".' So such new urban development, although it helps residents as their houses are the legacy of Hội An, other aspects such as development within the agricultural zone are left to one side. In this process, some authenticity is inevitably lost, and therefore tourism might be seen as inducing cultural investment that stands for inauthentic or, more bluntly, 'fake' experiences, undermining rather than strengthening our understanding of historical places.

One of the primary risks of strategically using culture to sell a city or town is the financial exploitation of the site. As Lask and

\footnotetext{
${ }^{34}$ Vietnamtourism, "Hoi An: 15 years as an UNESCO World Heritage Site". Accessed April 15, 2017. http://www.vietnamtourism.com/en/index.php/ news/items $/ 8727$

${ }^{35}$ Ursula James. "Real Culture Preservation. Authenticity, and Change in Hoi -An 's Heritage Tourism Industry" Independent Study Project (ISP) -Collection. 873,2010

${ }^{36}$ Nir Avieli. “The rise and fall of Hoi An, a UNESCO World Heritage Site in Vietnam.” Journal of Social Issues in Southeast Asia 30, no. 1 (2015): 35-71.

${ }^{37}$ Timothy, Dallen. Cultural Heritage and Tourism: An Introduction. (Bristol: Channel View Publications, 2011).

${ }^{38}$ Berry, Brian Joe Lobley. “Approaches to urban policymaking: a framework.” - in International Handbook of Urban Policy, Volume 1: Contentious Global Issues, ed. Herman Geyer (Cheltenham: Edward Elgar Publishing Limited, 2007), 1-8.

${ }^{39}$ Gareth Shaw and Allan Williams. Critical Issues in Tourism: A Geographical Perspective. (Oxford: Blackwell Publishing, 2002)

${ }^{40}$ David Harrison. "Introduction: Contested Narratives in the Domain of World -Heritage." Current Issues in Tourism 7, no.4-5 (2004): 283.
} 
Herold ${ }^{41}$ suggest: 'the place becomes over-commercialised and disfigured. In fact, protection has been replaced by commercial exploitation.' This is an inherent risk for both Valparaíso and Hội An, since projecting the heritage sites as brands, can easily contribute and encourage the behaviour of tourists to consume which, after 'explosive' returns at the beginning, inevitably starts to diminish as the heritage site experiences 'brand decay' ${ }^{42}$. In this sense, a sustainable strategy in selling the city is to develop a continuous cycle of investment in cultural infrastructure to re-engage tourists and maintain the attractiveness of the place. Such an evaluation has been considered in regards to Valparaíso's cultural capital, with, for example, the reopening of the Museum of Natural History in $2014^{43}$ and the inauguration of the biggest cultural centre of the city, Parque Cultural de Valparaíso, in 2012.

Such overly narrow analyses, as those based purely on the economic results of cultural investment are detrimental in so far as they cannot capture the middle- and long-term disadvantages. In this regard, Lask and Herold ${ }^{44}$ suggest the use of an observation station to analyse both local and national social structures and monitor the impact of tourism, in order to develop such tourism sustainably. Additionally, Timothy and Tosun ${ }^{45}$ suggest a participatory, incremental and collaborative model- The PIC planning model - which empowers the community to make decisions about tourist attractions. This allows local communities to monitor the strategy of promotion and make changes - when necessary - sidestepping the bureaucracy of central governments, as well as preventing the territorial conflicts concomitant in their management between public agencies, fostering collaboration for the sake of longer-term sustainable tourism.

\section{Conclusion}

Although both case studies enjoy the same condition of being nominated to the WHL, each location's strategy to make their culture instrumental to sell the city/town has been dramatically different. The main difference is laid down by the roles of local governments and their commitment to sustainable tourism. The different situations can be best understood through the political context of the countries involved: in the case of Valparaíso, Chile, a neoliberal administration gives more emphasis and liberty to the intervention of the private sector. As a consequence, a more commercialised form of tourism has been developed after its nomination to the WHL in 2003, in which the large quantity of new business license granted has forced and continues to force the local community to move to other areas. Those who decide to stay, generally low-income families, are confined to reduced spaces, diminishing their life quality and giving more openings to hotels, bars and shops complementing the heritage aspect of the touristic experience.

On the contrary, the centralised, communist influence of the Vietnamese government leads to a far larger public role in the administration of the ancient town of Hội An. Additionally, while cultural investment in the buildings is assumed by the local government, it also considers that the community, as the owners of the buildings, must participate in and propose the regeneration of their houses and pay a percentage for the improvement of infrastructure. This integration helps to increase participation of the local people in the preservation of the site, whilst simultaneously boosting commitment to the place's branding and manner of promotion.

In the end, being nominated by UNESCO seems to represent a 'double-edged sword'. While bringing touristic benefits, the nomination also comes with complex responsibilities as regards the strategy with which tourists are sold the city/town's brand in a way that sustains rather than undermines its own heritage. It seems that recognising the global plan of the WHL in both national and local contexts is the most effective way for tourists to authentically experience the said heritage, and therefore ensure the sustainability of cultural investment and keep the interests of all the different stakeholders balanced.

\footnotetext{
${ }^{41}$ Tomke Lask and Stefan Herold. “An Observation Station for Culture and Tourism in Vietnam: A Forum for World Heritage and Public Participation.” in The Politics of World Heritage, ed. David Harrison and Michael Hitchcock (Bristol: Channel View Publication, 2005), 123.

${ }^{42}$ Graeme Evans. "Hard-Branding the cultural city: from Prado to Prada.” International Journal of Urban and Regional Research 27, no.2 (2003): 417-440.

${ }^{43}$ INE, Estadisticas Culturales: Informe Anual 2015. (Santiago: A Impresores S.A, 2016).

${ }^{44}$ Tomke Lask and Stefan Herold. "An Observation Station for Culture and Tourism in Vietnam: A Forum for World Heritage and Public Participation." in The Politics of World Heritage, ed. David Harrison and Michael Hitchcock (Bristol: Channel View Publication, 2005), 119-131.

${ }^{45}$ Cevat Tosun and Timothy Dallen. "Arguments for community participation- in the tourism development process." Journal of Tourism Studies 14,- no.2 (2003): $2-15$
} 


\section{Bibliography}

Alexander, André, Leonhardt, Maurice and Nguyen Huong. Hoi An, Vietnam-Mission Report. Bangkok: ACHR Asian Heritage Project, 2011.

El Martutino. “Así será el Nuevo Mall Barón en Valparaíso”. Accessed April- 30, 2017. http://www.elmartutino.cl/ noticia/sociedad/fotos-asi-sera--el-nuevo-mall-baron-en-valparaiso

Avieli, Nir. "The rise and fall of Hoi An, a UNESCO World Heritage Site in -Vietnam." Journal of Social Issues in Southeast Asia 30, no.1 (2015):-35-71.

Babcock, Julia. "Vietnam's Hoi An and The Resilience of Culture" Ecotrust,- February 19, 2013, https://ecotrust.org/ hoi-an-vietnam-and-the--_ resilience-of-culture/

Berry, Brian Joe Lobley. “Approaches to urban policymaking: a framework." - In International Handbook of Urban Policy, Volume 1: Contentious-GlobalIssues, edited by Herman Geyer, 1-8. Cheltenham: Edward--Elgar Publishing Limited, 2007. Coccossis, Harry. "Sustainable Development and Tourism: Opportunities and- Threats to Cultural Heritage from Tourism." In Cultural Tourism and-Sustainable Local Development, edited by Luigi Fusco Girard and-- Peter Nijkamp, 47-56. Surrey: Ashgate Publishing Limited, 2009.

Dong Nguyen. "French Photographer opens art gallery museum to preserve -Vietnam's ethnic culture" Tuoi Tre News, January 23, 2017.-- http://tuoitrenews.vn/lifestyle/39304/french-photographer-opens-art--gallery-museum-topreserve-vietnams-ethnic-culture.

Evans, Graeme. "Hard-Branding the cultural city: from Prado to Prada."-- International Journal of Urban and Regional Research 27, no.2 -(2003): 417-440.

Evans, Graeme. "Measure for Measure: Evaluating the Evidence of Culture's- Contribution to Regeneration. "Urban Studies 42, no.5 (2005): 959--983.

Festival de las Artes. "Festival de las Artes 2017 "Accessed March 15, 2017. - http://festivaldelasartes.cultura.gob.cl/. Griffiths, Ron. "Cultural Strategies and new modes of urban intervention.” -Cities 12, no. 4 (1995): 253-265.

Hidalgo, Rodrigo, Borsdorf, Axel, and Gabriel San Martín. "Socio-spatial-- change in the world heritage site Valparaíso." Journal of the-_ Geographical Society of Berlin 144 no.3 (2013): 228-240.

Harrison, David. "Introduction: Contested Narratives in the Domain of World -Heritage." Current Issues in Tourism 7, no.45 (2004): 281-290.

INE, Estadísticas Culturales: Informe Anual 2015. Santiago: A Impresores- S.A, 2016.

James, Ursula. "Real Culture Preservation. Authenticity, and Change in Hoi -An's Heritage Tourism Industry" Independent Study Project (ISP) -Collection. 873, 2010.

Lask, Tomke and Stefan Herold. "An Observation Station for Culture and-- Tourism in Vietnam: A Forum for World Heritage and Public-- Participation.” In The Politics of World Heritage, edited by David-- Harrison and Michael Hitchcock, $119-131$. Bristol: Channel View--Publication, 2005.

Mil Tambores, "Festival Mil Tambores"Accessed March 15, 2017._- http://www.miltambores.cl/.

Morales, Margarita. Cultural Heritage and Urban Regeneration: The conflict- between Identity and Development Strategies in the city of - Valparaíso. UCL: Bartlett school of graduate studies University-- College London, 2013.

Montecinos, Egon. "Los actuales desafios regionales en Chile: ¿Nueva-- Regionalización o más Descentralización? XI Asamblea de--- las municipalidades" XI Congreso Nacional de Municipalidades, -January 8,9,10, 2013,-- -http:// munitel.cl/eventos/seminarios/html/documentos/2013/XI_AS-AMBLEA_DE_MUNICIPALIDADES/ CONGRESO/PPT10.pdf.

Nhung, Tuyet. "Hoi An Old Town - an ancient Beauty of Vietnam" - Vietnam-Beauty.com, August 7, 2008, http://www. vietnam--beauty.com/top-destinations/destination-in-the-central-region/12--destination-in-the-middle/43-hoian-old-town-an-ancient-beauty-of--vietnam.html

Ost, Christian. "Cultural Heritage, Local Resources and Sustainable Tourism:- Towards an Operational Framework for Policy and Planning." In:--Cultural Tourism and Sustainable Local Development, edited by-- Luigi Fusco Girard and Peter Nijkamp, 75-80. Surrey: Ashgate-- Publishing Limited, 2009.

Pratt, Andy. "The relationship between the City, Cultural Tourism and the-- Cultural Industries." Cultural Tourism. (Jan 2002): 33-45.

Parque Cultural Valparaíso. "Parque Cultural Valparaíso ”Accessed February- 22, 2017. http://parquecultural.cl/.

Ramos, Natalia. "Report reveals that only 50\% was completed in Valparaíso- patrimonial work." La Bicicleta Verde, June 30, 2013-_- https:/ / labicicletaverde.com/report-reveals-that-50-was-completed-in--valparaiso-patrimonial-works/. Shaw, Gareth and Allan Williams. Critical Issues in Tourism: A-_-Geographical Perspective. Oxford: Blackwell Publishing, 2002 . 
Tosun, Cevat and Dallen Timothy. "Arguments for community participation- in the tourism development process." Journal of Tourism Studies 14,-no.2 (2003): 2-15.

Timothy, Dallen. Cultural Heritage and Tourism: An Introduction. Bristol:- Channel View Publications, 2011.

UNESCO. "Hoi An Ancient Town." WHC nomination documentation, — December 4, 1999._-_-_-_- http://whc. unesco.org/uploads/nominations/948.pdf

UNESCO. Culture Heritage Management and Tourism: Models for Co--operation among Stakeholders. A case study on Hoi An Vietnam. - Bhaktapur: UNESCO, 2000.

UNESCO. "Historic Quarter of the Seaport City of Valparaiso." WHC_- nomination documentation, July 5, 2003.

http://whc.unesco.org/uploads/nominations/959rev.pdf.

UNESCO. IMPACT: The effects of Tourism on Culture and the Environment-in Asia and the Pacific: Cultural Tourism and Heritage-Management. Bangkok: UNESCO, 2008.

UNESCO, "Global Strategy. ”Accessed April 12, 2017._-_- http://whc.unesco.org/en/globalstrategy/.

Vietnamtourism, "Hoi An: 15 years as an UNESCO World Heritage Site."-- Accessed April 15, 2017.-http://www. vietnamtourism.com/en/index.php/news/items/8727 